\title{
Identifikasi Urban Heat Island di Kota Solok menggunakan Algoritma Landsat-8 OLI Landsurface Temperature
}

\author{
Masuk: 23032018 / Diterima: 28062018 / Dipublikasi: 30062018 \\ (C) 2018 Fakultas Hukum dan IImu Sosial UNDIKSHA dan IGI
}

Adenan Yandra Nofrizal, Muhammad Hanif

\begin{abstract}
Development that occurred in the city of Solok will lead to changes in land use. Land use changes that occur with rising land will cause rise in surface temperature (surface temperature) that can cause an urban heat island. This study aims to determine the surface temperature in Solok city and urban heat island phenomenon and the relationship between land use change to surface temperature causing urban heat island in Solok City area. The method used in this research is by using one of Land Surface Temperature model to know surface temperature by using digital image processing application besides also using Object Base Image Analyst (OBIA) method to get existing land use in Solok City. Using the method used will be obtained surface temperature in Solok City and Urban Heat Island phenomenon area and land use relationship with surface temperature
\end{abstract}

Key words: Surface Temperature; OBIA; Land Use

\begin{abstract}
Abstrak Pembangunan yang terjadi di Kota Solok akan menyebabkan terjadinya perubahan penggunaan lahan. Perubahan penggunaan lahan yang terjadi dengan meningkatnya lahan terbangun akan menyebabkan naiknya suhu permukaan (surface temperature) yang dapat menyebabkan terjadinya urban heat island. Penelitian ini bertujuan untuk mengetahui suhu permukaan yang ada di Kota Solok dan daerah fenomena urban heat island dan hubungan antara perubahan penggunaan lahan terhadap suhu permukaan yang menyebabkan terjadinya urban heat island di daerah Kota Solok. Metode yang digunakan dalam penelitian ini yaitu dengan menggunakan salah satu model Land Surface Temperature untuk mengetahui suhu permukaan dengan menggunakan aplikasi pengolahan citra digital selain itu juga menggunakan metode Object Base Image Analyst (OBIA) untuk mendapatkan penggunaan lahan yang ada di Kota Solok. Dengan menggunakan metode yang digunakan akan didapatkan suhu permukaan yang ada di Kota Solok dan daerah fenomena Urban Heat Island serta hubungannya penggunaan lahan dengan suhu permukaan.
\end{abstract}

Kata Kunci : Suhu Permukaan; OBIA; Penggunaan Lahan

1. Pendahuluan

Perkembangan suatu kota dapat mengakibatkan terjadinya perubahan penggunaan lahan daerah perkotaan terutama daerah non lahan terbangun menjadi lahan terbangun. Pembangunan infrastruktur dan bangunan yang tidak terkendali menyebabkan kurangnya vegetasi didaerah perkotaan. Pesatnya

Adenan Yandra Nofrizal

Jurusan Geografi, FIS Universitas Negeri Padang

Padang

adenannofrizal23@gmail.com perkembangan lahan terbangun dapat menyebabkan terjadinya peningkatan suhu permukaan perkotaan. Perubahan penutupan lahan dapat reflektansi radiasi surya permukaan bumi yang dapat menyebabkan pendinginan ataupun pemanasan lokal (Handayani, 2007). Perubahan penggunaan lahan yang terjadi tersebut dapat berdampak pada perubahan pada unsur-unsur iklim. Perubahan unsur iklim yang terjadi adalah suhu, radiasi matahari, kecepatan angin, dan awan (BSNI, 2010). 
Dari empat unsur iklim tersebut, yang dapat dirasakan langsung perubahannya adalah suhu. Perubahan tata guna lahan ataupun konversi lahan menjadi lahan terbangun mempengaruhi suhu permukaan, yang selanjutnya akan mempengaruhi suhu udara. Bahan bangunan seperti aspal, semen, dan beton menjadi penyerap dan penyimpanan panas matahari (Tursilowati, 2002). Suhu wilayah pada perkantoran dan jalan aspal mengalami perubahan yang tinggi, berbeda dengan kawasan yang bervegetasi yang memiliki suhu permukaan yang lebih rendah. Adanya perbedaan suhu di kawasan kota yang padat bangunan dengan kawasan pinggiran kota yang masih didominasi oleh tutupan vegetasi dikenal dengan nama heat island atau "pulau panas".

Pengkonversian lahan bervegetasi menjadi kawasan- kawasan pembangunan di daerah perkotaan menyebabkan beberapa dampak negative pada lingkungan. Meningkatnya suhu udara dapat mengurangi mutu lingkungan hidup, berkurangnya kenyamanan kota dan buruknya kualitas udara di kawasan perkotaan yang berdampak pada menurunnya tingkat kesehatan masyarakat. Selain itu, polutan- polutan yang berbentuk gas dan partikel kecil di atmosfer seperti $\mathrm{CO}, \mathrm{CO} 2$, $\mathrm{Pb}, \mathrm{NOx}$, SOx, dan CFC yang merupakan hasil aktivitas kegiatan manusia, akan bergerak dan terkonsentrasi menuju kawasankawasan yang bersuhu lebih tinggi.

Kota Solok merupakan salah satu kota yang berada di Provinsi Sumatera Barat yang memiliki pertumbuhan penduduk yang cukup pesat, pertumbuhan penduduk yang semakin padat maka membutuhkan ruang untuk tempat tempat tinggal, terutama pada daerah perkotaan. Hal ini dapat menyebabkan terjadinya pembangunanpembangunan lahan terbangun. Konversi lahan menjadi lahan terbangun yang terjadi di Kota Solok dapat mengakibatkan terjadinya peningkatan suhu permukaan yang ada di Kota Solok terutama pada daerah perkotaan atau yang dapat disebut dengan urban heat island. Kurangnya vegetasi akibat konversi lahan dari non lahan terbangun menjadi lahan terbangun yang terjadi di bagian perkotaan di Kota Solok akan mengakibatkan semakin mempercepat terjadinya kenaikan suhu permukaan yang ada di Kota Solok yang mempermudah terjadinya Urban Heat Island di Kota Solok.

Dengan demikian diperlukan adanya pembangunan wilayah yang terencana untuk menjaga dan memperbaiki kualitas udara di Kota Solok. Pembenahan tata ruang perkotaan dengan menentukan kawasan-kawasan untuk tiap penggunaan lahan. Oleh karena itu perlu dilakukan suatu kajian tentang sebaran suhu permukaan pada berbagai penutupan lahan di Kota Solok. Harapan jangka menengah dan panjangnya adalah Kota Solok menjadi kota yang lebih nyaman, lebih bersih dan lebih sehat.

Teknologi yang dapat digunakan untuk mendapatkan informasi dengan cepat tentang jenis penutupan lahan dan sebaran suhu permukaan Kota Solok adalah dengan menggunakan data penginderaan jauh atau citra satelit sumberdaya, khususnya citra Landsat. Citra Landsat yang dapat digunakan yaitu dengan citra Landsat-8 OLI yang dilakukan proses pengolahan citra digital tersebut dengan menggunakan aplikasi pengolahan citra digital. Citra Landsat-8 OLI digunakan untuk memperoleh penggunaan lahan dan suhu permukaan di Kota Solok yang selanjutnya akan digunakan untuk identifikasi urban heat island yang ada di Kota Solok.

Landsat 8 menggunakan perhitungan dan kalibrasi skala Digital Number (DN) yang merepresentasikan gambar multispectral menggunakan dua hal yaitu Operational Land Imager (OLI) 
dan Thermal Infrared Sensor (TIRS) (Ikhwan, 2013). Produk landsat 8 menggunakan format data 16-bit unsigned integer yang dapat dirubah menjadi radiance dan reflectance Top Of Atmosphere (TOA). Suhu permukaan dapat diartikan suhu bagian terluar dari suatu obyek. Untuk suatu tanah terbuka, suhu permukaan adalah suhu pada lapisan terluar permukaan tanah sedangkan untuk vegetasi seperti hutan dapat dipandang suhu permukaan kanopi tumbuhan dan pada tubuh air merupakan suhu dari permukaan air tersebut. Pada saat permukaan suatu benda menyerap radiasi, suhu permukaannya akan meningkat. $\mathrm{Hal}$ ini juga akan meningkatkan fluks energi (radiasi gelombang panjang) yang keluar dari permukaan benda tersebut. Suhu permukaan bukanlah suhu udara, keduanya memiliki nilai aktual yang bervariasi menurut ruang dan waktu. Suhu permukaan berpengaruh terhadap fluks bahang terasa (sensible heat), terutama pada siang hari, karena suhu permukaan benda lebih tinggi dibandingkan dengan suhu udara (Wiweka, 2014).

Penelitian ini bertunjuan untuk mengidentifikasi urban heat island yang terjadi pada wilayah Kota Solok dan hubungan antara suhu permukaan dengan pengunaan lahan yang ada di Kota Solok.

\section{Metode}

Penelitian ini dilakukan di Kota Solok yang secara geografis Kota Solok berada pada posisi $0^{\circ} 44^{\prime 2} 28^{\prime \prime}$ LS sampai $1^{\circ} 49^{\prime} 12^{\prime \prime}$ LS dan $100^{\circ} 32^{\prime} 42^{\prime \prime}$ BT sampai $101^{\circ} 41^{\prime} 12$ " BT terdiri dari daerah datar, gelombang, curam, sangat curam dan berbukit dengan ketinggian rata-rata mencapai 390 meter di atas permukaan laut. Kota Solok sendiri memiliki luas 57, $64 \mathrm{~km}^{2}(0,14$ persen dari luas Provinsi Sumatera Barat). Kota Solok memiliki 2 kecamatan yaitu Kecamatan Tanjung Harapan dan Kecamatan Lubuk Sikarah.
Kota Solok dikelilingi oleh beberapa nagari pada Kabupaten Solok, dimana Kota Solok memiliki peran sentral di dalam menunjang perekonomian masyarakat Kota Solok dan Kabupaten Solok pada umumnya. Secara administrasi wilayah Kota Solok berbatasan langsung dengan nagari -nagari di Kabupaten Solok diantaranya sebelah utara berbatasan dengan Nagari Tanjung Bingkung dan Nagari Kuncir, sebelah selatan berbatasan dengan Nagari Gaung dan Nagari Panyakalan, sebalah barat berbatasan dengan Nagari Salayao dan Kota Padang sedangkan sebelah timur berbatasan dengan Nagari Saok Laweh, Nagari Guguk Sarai dan Nagari Gaung (Nofrizal, 2017).

Penelitian ini menggunakan pendekatan deskriptif kuantitatif dengan melakukan pengolahan citra digital dengan menggunakan aplikasi berbasis penginderaan jauh dan aplikasi berbasis Sistem Informasi Geografi (SIG) (Nofrizal, 2018).

\section{A. OBIA ( Object Base Image Analyst)}

Untuk mendapatkan hasil dari klasifikasi penggunaan lahan di Kota Solok, peneliti mengkalisifikasikan penggunaan lahan dengan 6 tipe penggunaan lahan yaitu;
1. Hutan
2. Kebun Campuran
3. Tanah Terbuka
4. Sawah
5. Semak Belukar
6. Lahan terbangun

Metode Object Base Image Analyst (OBIA) dilakukan dengan menggunakan aplikasi pengolahan citra digital yaitu ENVI versi 5.1. Metode Object Base Image Analyst (OBIA) sangat cocok dilakukan untuk proses interpretasi citra dengan menggunakan ukuran piksel citra yang memiliki resolusi tinggi dan sedang (Baschke, 2010; Strahler, 1986; Ohao, 2011). Menggunakan citra Landsat8 OLI yang memiliki resolusi sedang dan telah dipertajam resolusinya dengan proses 
pansharpening. Metode Object Base Image Analyst (OBIA) memiliki 2 proses tahapan, yang pertama yaitu proses segmenatsi piksel berdasarkan struktur objek pada piksel, panjang gelombang dan juga bentuk objek, selanjutnya yaitu proses klasifikasi yang dilakukan secara manual dan pengkoreksian data. Sehingga dapat dihasilkan klasifikasi penggunaan yang baik dan akurat (Hanif, Nofrizal, \& Yurni, 2017).

\section{B. Landsurface Temperature}

Landsurface

temperature merupakan sebuah metode pengolahan citra digital untuk melakukan pengolahan suhu permukaan yang berbasis penginderaan jauh dengan menggunakan kanal band thermal.

Prinsip dasar yang dikembangkan dalam deteksi suhu udara mengacu kepada prinsip fisika caha pada black body temperature. Pada dasarnya setiap panjang gelombang akan sensitif terhadap respon suhu permukaan yang mempengaruhi nilai pantul objek (Tursilowati, 2007).

Citra suhu permukaan diperoleh dengan cara mengkonversi nilai digital kanal 6 (inframerah termal) ke dalam spektral radian menggunakan formula (USGS, 2001):

$$
L Y=L \min +\{((\max -L \min ) / 255) D N\}
$$

Dimana :

$\mathrm{LY}=$ spektral radian $(\mathrm{Wm}-2 \mathrm{sr}-1 \mathrm{~m}-2)$

$\mathrm{Lmin}=$ spektral radian maksimal untuk kanal 6 (Wm-2sr-1 m-2).

Lmin kanal 6Low $=0$ Wm-2sr-1 m-2

Lmin kanal $6 \mathrm{High}=3.200 \mathrm{Wm}-2 \mathrm{sr}-1 \mathrm{~m}-2$

Lmax = spektral radian maksimum untuk kanal 6 (Wm-2sr-1 m-2)

Lmax kanal 6 Low $=17.04 \mathrm{Wm}-2 \mathrm{sr}-1 \mathrm{~m}-2$

Lmax kanal $6 \mathrm{High}=12.650 \mathrm{Wm}-2 \mathrm{sr}-1 \mathrm{~m}-2$

(Ket : Lmin dan Lmax diperoleh dari file MTL LS-7_ETM)

$\mathrm{DN}=$ nilai digital $(0-255)$

Dengan mengasumsikan emisivitas permukaan adalah satu, maka formula yang digunakan untuk menghitung suhu permukaan adalah

(USGS, 2002):
$\mathrm{Ts}=\mathrm{K} 2 / \ln (\mathrm{K} 1 / \mathrm{Ly}+1)(3.2)$

Dimana :

Ts = Suhu permukaan (Kelvin)

$\mathrm{K} 1=$ Konstanta kalibrasi $1=666.09(\mathrm{Wm}-2 \mathrm{sr}-$ $1 \mathrm{~m}-2)$

$\mathrm{K} 2=$ Konstanta kalibrasi $2=1282.719$ (Kelvin)

$L Y=$ Spektral radian $(\mathrm{Wm}-2 \mathrm{sr}-1 \mathrm{~m}-2)$

Untuk mengkonversi nilai suhu permukaan ke dalam oC, nilai yang diperoleh dikurangi 273.

Algoritma Landsat OLI 8 Landsurface Temperatur

Analisis suhu permukaan lahan atau tanah menggunakan band 10 pada Landsat Oli 8 , band 10 pada landsat oli dapat digunakan untuk mengindikasikan suhu permukaan daratan. Sederhananya ada beberapa tahap yang dilakukan untuk menganalisis suhu permukaan daratan merubah nilai spectral menjadi nilai radian, merubah radian menjadi derajat temperatur kelvin, dan mengubah derajat temperatur kelvin menjadi derajat celcius.

\section{TOA to Radiance}

Top of Atmospheir atau dikenal dengan TOA yang merupakan data reflectan. Pada tahap ini kita akan merubah nilai digital number (DN) citra band TIRS landsat OLI menjadi data Radiance.

Formula yang dipublikasikan USGS

$$
L=M L Q c a l+A L
$$

Sumber: $\underline{\text { http://landsat.usgs.gov }}$

Radiance to Temperature

Formula perhitungan secara matematis yang dipublikasian USGS untuk konversi data sebagai berikut:

$$
T=\frac{K 2}{1 n\left\{\frac{K 1}{L \lambda}+1\right\}}
$$

$\mathrm{T}:$ Suhu derjat Kelvin

$L \lambda$ : TOA Spectral radiance (Watts $/(\mathrm{m} 2$ $\left.{ }^{*} \operatorname{srad}^{*} \mu \mathrm{m}\right)$

K1 dan K2 : Konstanta pada band 10 atau band 11 dilihat dalam text informasi citra/ text metadata (K1_KONSTANT_BAND_X) dimana $X$ adalah nomor band.

Sumber: http://landsat.usgs.gov 


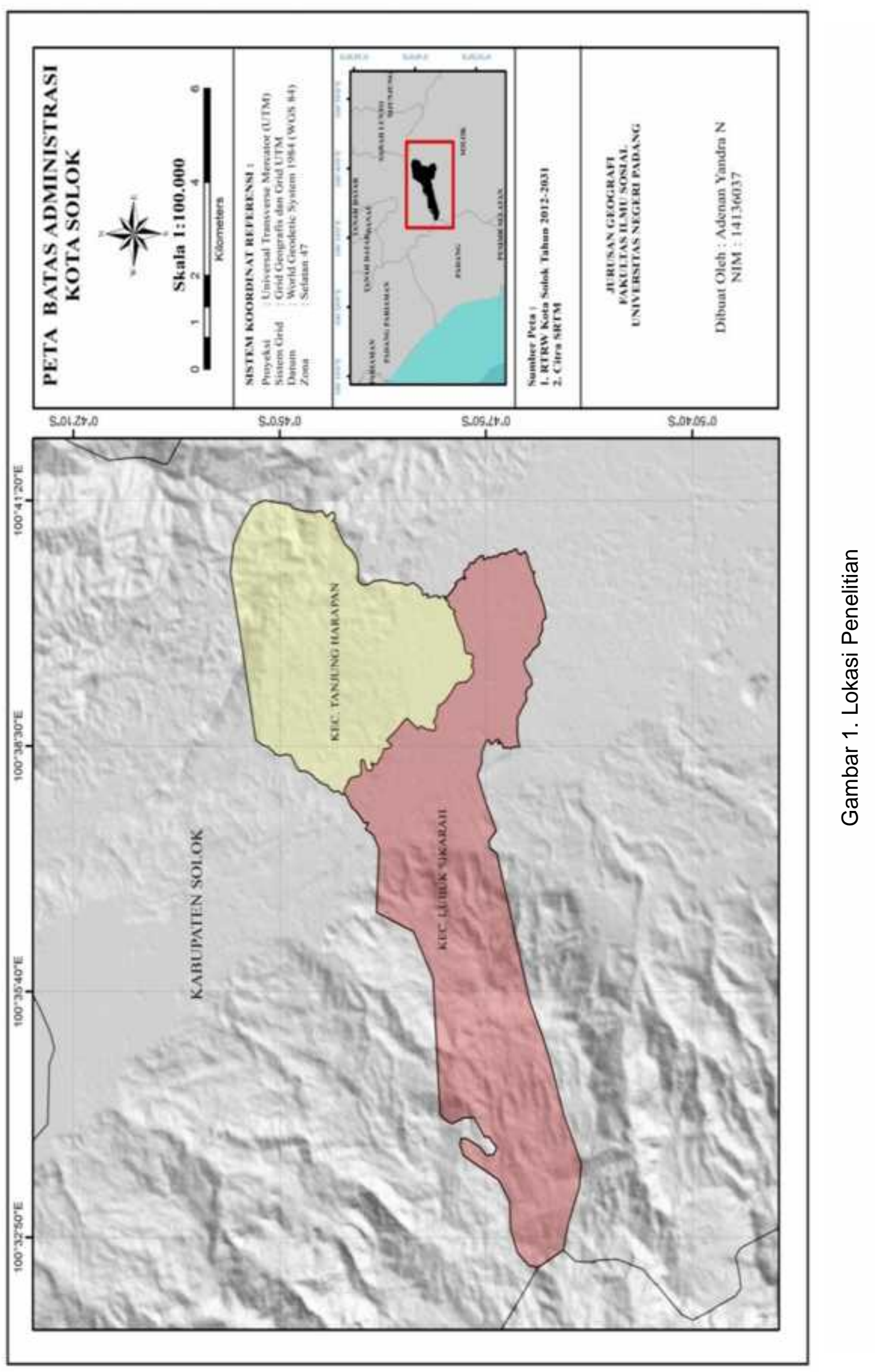


C. Impact penggunaan lahan terhadap landsurface temperature

Analisis pengaruh variabel independen yang digunakan terhadap regresi linear berganda. Sampel yang digunakan, terdiri dari perubahan suhu pixel dan tidak, dengan sampel grid $30 \mathrm{~m}$ $X$ 30m (Ikhwan, 2013). Sebagai variabel bebasnya adalah hutan, kebun campuran, semak belukar, Tanah Terbuka, sawah dan permukiman. Selanjutnya dilakukan korelasi antara penggunaan lahan dan suhu permukaan dengan menggunaan software spss, untuk melihat keterkaitan antara penggunaan lahan dan suhu permukaan.

\section{Hasil dan Pembahasan}

a. Penggunaan Lahan Kota Solok

Proses hasil klasifikasi citra Landsat8 yang bersumber dari USGS dengan melakukan pengolahan menggunakan aplikasi pengolahan citra digital yaitu ENVI 5.1 dengan menggunakan metode Object Base Image Analyst (OBIA) serta proses generalisasi dengan menggunakan apikasi berbasis Geography Information System (GIS). Didapatkan hasil luas penggunaan lahan di Kota Solok pada tahun 2015 sebagai berikut.

Tabel 1. Penggunaan Lahan Kota Solok

\begin{tabular}{ccc}
\hline No & Penggunaan Lahan & Luas (Ha) \\
\hline 1 & Hutan & 2.290 \\
2 & Kebun Campuran & 1.650 \\
3 & Lahan Kosong & 34 \\
4 & Sawah & 900 \\
5 & Semak Belukar & 258 \\
6 & Lahan Terbangun & 952 \\
\hline
\end{tabular}

Sumber : Badan Standarisasi Nasional 2010.

Berdasarkan tabel 4 dapat diketahui penggunaan lahan di Kota Solok yang paling luas yaitu Hutan dengan luas hutan di Kota Solok pada tahun 2015 yang didapatkan dari hasil pengolahan citra landsat 7 yaitu seluas 2.290 hektar dan yang paling sedikit yaitu Lahan Kosong yang berupa tanah terbuka yang memiliki luas 34 hektar. Kota Solok memiliki luas lahan terbangun pada tahun 2000 yaitu seluas lahan terbangun yaitu 952 Hektar.

\section{b. Suhu Permukaan di Kota Solok}

Setelah melakukan download citra satelit berupa citra landsat8 band 10 yang merupakan band thermal, sebelum melakukan proses analisis citra,dilakukan pemotongan pada citra tersebut sesuai dengan wilayah administrasi penelitian yaitu Batas Administrasi Kota Solok.
Berdasarkan hasil dari pengolahan citra digital dengan menggunakan metode landsurface termperatur dengan menggunakan aplikasi pengolahan citra digital menggunakan band 10 yang merupakan band thermal dengan tiga tahap yaitu TOA to radiance, radiance to temperature. Maka di Kota Solok sendiri memiliki suhu tertinggi yaitu mencapai $36^{\circ} \mathrm{C}$ dan suhu terendah mencapai $20^{\circ} \mathrm{C}$. Dari hasil pengolahan citra tersebut dapat dilihat suhu permukaan yang ada di Kota Solok itu sendiri sangat beragam, hal ini disebabkan karena adanya perbedaan penggunaan lahan yang ada di Kota Solok yang beragam, mulai dari Hutan, Kebun Campuran, Semak Belukar, Tanah Terbuka, Sawah dan Lahan Terbangun. 

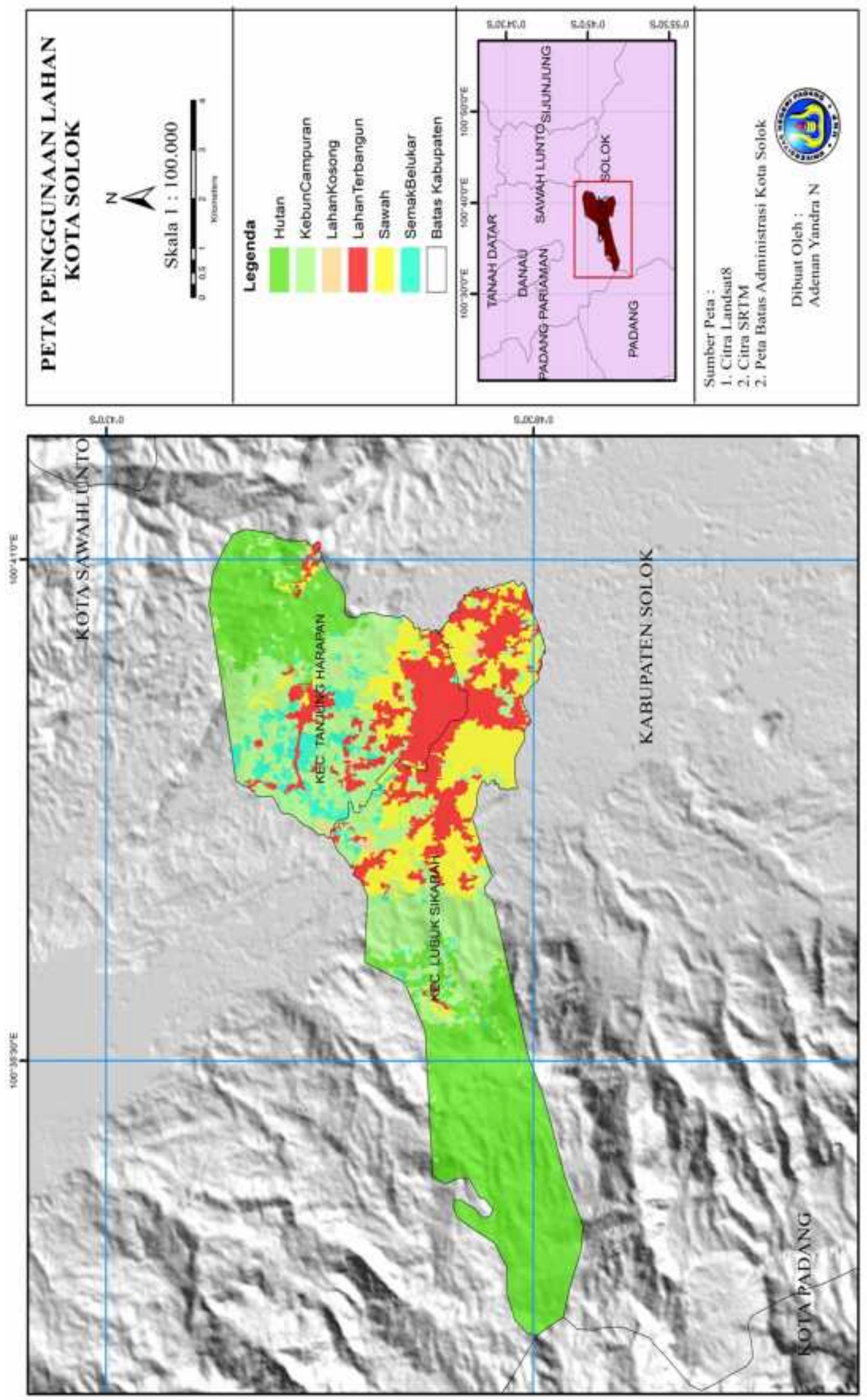

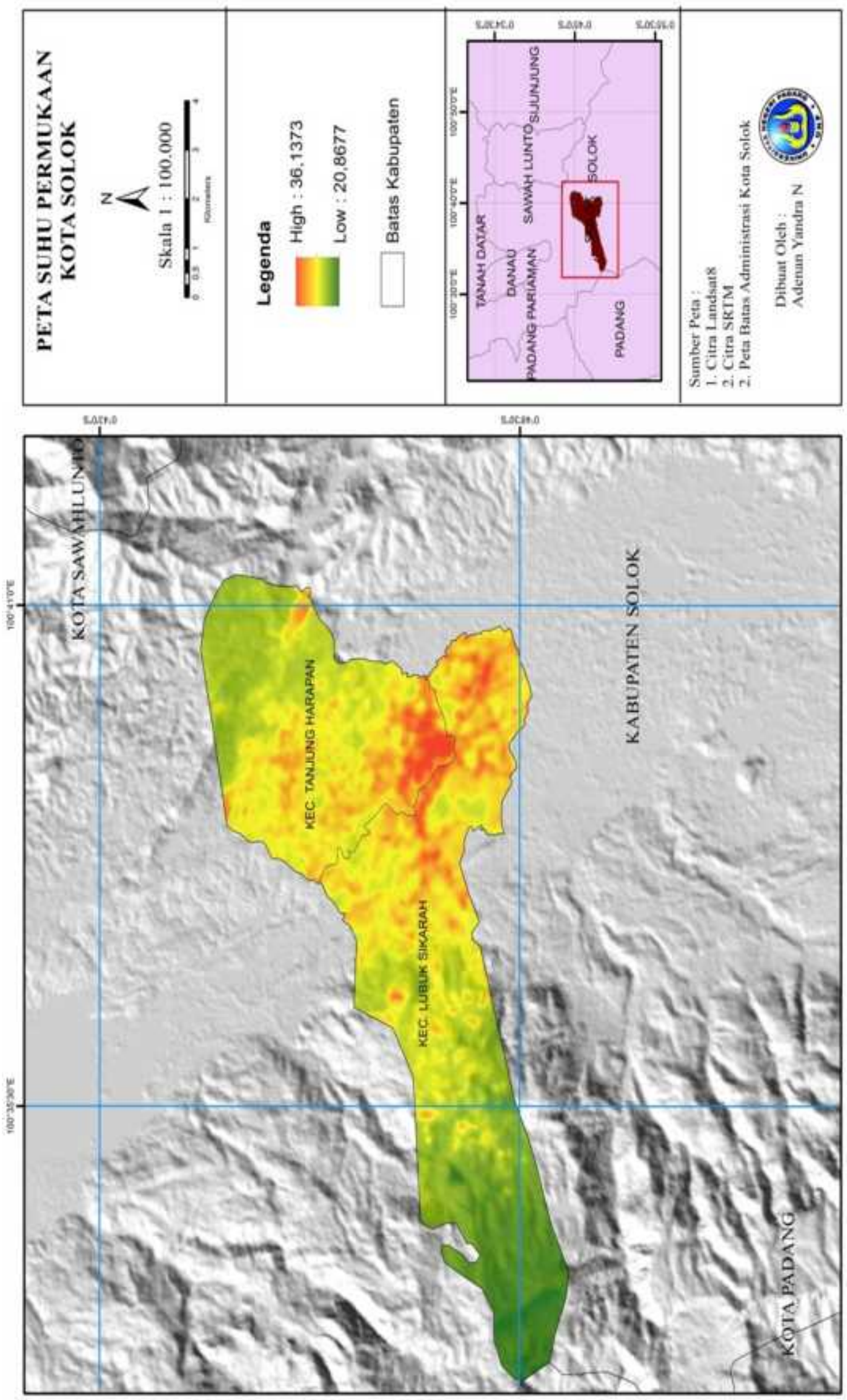

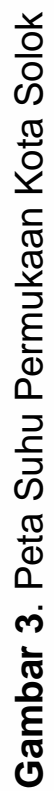



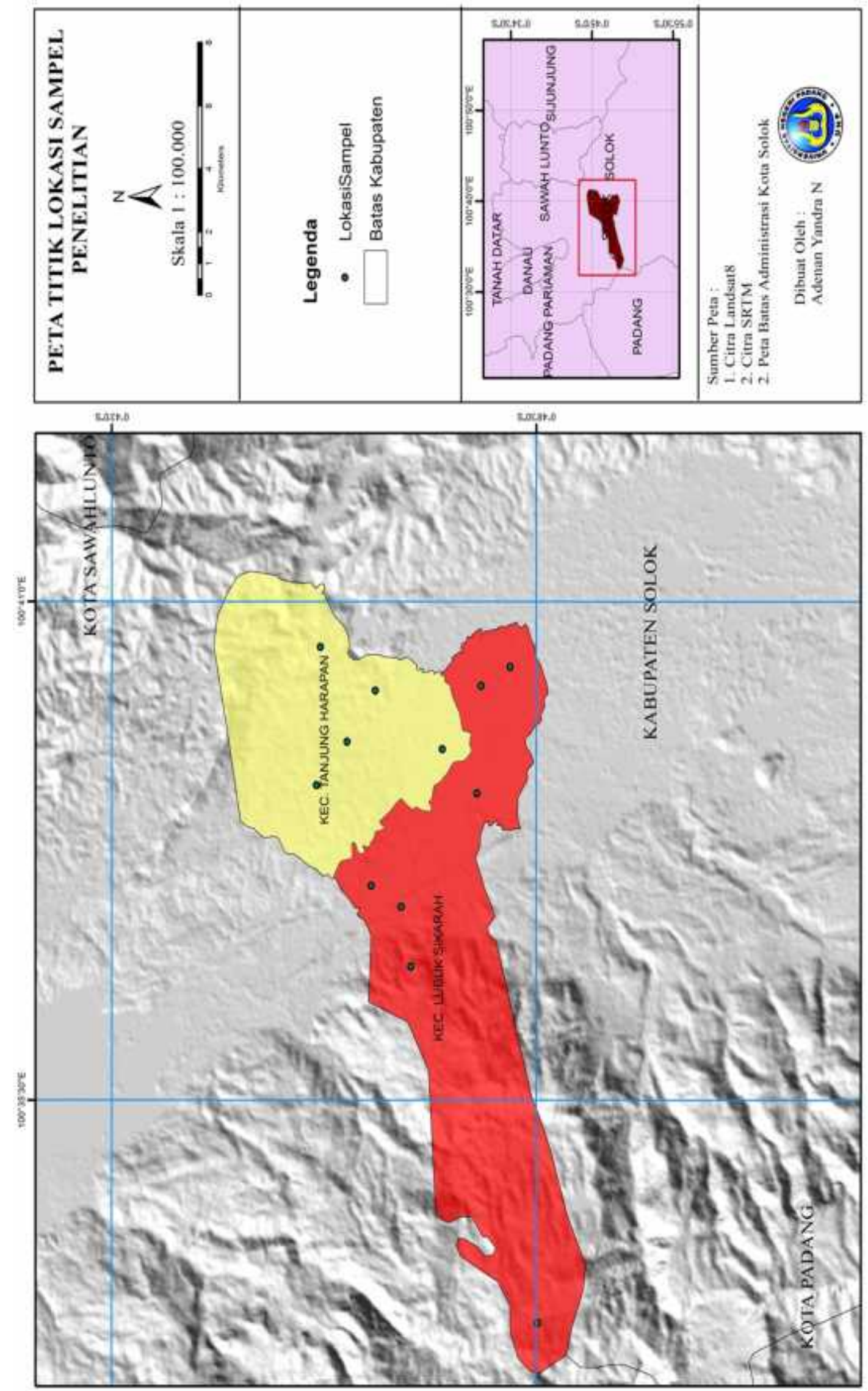

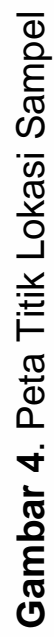


Selain disebabkan oleh penggunaan lahan yang beragam, perbedaan suhu permukaan yang ada di Kota Solok juga disebabkan oleh perbedaan ketinggian yang ada di Kota Solok, Selain itu perbedaan suhu permukaan yanga da di Kota Solok juga disebabkan karena adanya aktivitas manusia yang berupa aktivitas industri, aktivitas transportasi. Suhu permukaan yang tertinggi yang terjadi di Kota Solok yaitu dengan mencapai $36^{\circ} \mathrm{C}$ yaitu terjadi pada wilayah perkotaan yang merupakan penggunaan lahannya yaitu lahan terbangun, sedangkan suhu terendah yaitu dengan suhu $20^{\circ} \mathrm{C}$ yaitu berada pada kawasan hutan yang penggunaan lahan nya yaitu hutan yang di dominasi vegetasi dengan jenis vegetasi yaitu hutan dengan pohon" pohon besar dengan kerapatan yang tinggi.

c. Hubungan Penggunaan Lahan dan Suhu Permukaan di Kota Solok

Untuk mengetahui hubungan antara penggunaan lahan yang ada di Kota Solok yaitu meliputi Hutan, Kebun Campuran, Semak Belukar, Sawah, Tanah Terbuka, dan Lahan Terbangun dengan suhu permukaan yang ada di Kota Solok. Maka dilakukan uji koefisien korelasi antara penggunaan lahan Kota Solok dan suhu permukaan Kota Solok dengan pengambilan titik sampel sebanyak 12 sampel dengan menggunakan teknik purposive sampling dimana setiap penggunaan lahan didapatkan 2 sampel untuk mewakili setiap penggunaan lahan. Setelah dilakukan proses korelasi dengan menggunakan software SPSS. Maka didapatkan nilai korelasi yaitu sebesar 0,463 yang mana berarti memiliki hubungan nilai yang kuat.

\section{Kesimpulan}

Berdasarkan hasil penelitian mengenai suhu permukaan di Kota Solok dengan menggunakan algoritma LandSurface temperature maka dapat diketahui :

1. Kota Solok memiliki suhu permukaan yang beragam suhu permukaan yang tertinggi di Kota Solok mencapai $36^{\circ} \mathrm{C}$ dan suhu permukaan yang terendah di Kota Solok yaitu $20^{\circ} \mathrm{C}$.

2. Penggunaan Lahan yanga da di Kota Solok juga mempengaruhi suhu permukaan yang ada di Kota Solok hal ini dapat dilihat dari hubungan analisis korelasi yang telah dilakukan yang didapatkan suhu permukaan tertinggi yaitu berada pada lahan terbangun dan suhu terendah yaitu pada penggunaan lahan hutan.

\section{Daftar Pustaka}

Baschke, et al. (2010). Object Base Image Analysis for Remote Sensing. Journal of Photogrammetry and Remote Sensing, 65, 2-16.

BSNI. (2010). Klasifikasi Penutup Lahan. Jakarta: Badan Standarisasi Nasional.

Handayani. (2007). Identifikasi Perubahan Kapasitas Panas Kawasan Perkotaan Dengan Menggunakan Citra Landsat TM/ETM (Studi Kasus: Kodya Bogor). FMIPA IPB.

Hanif, Nofrizal, A. Y., \& Yurni. (2017). Investigation Character of Natural Forest Ecosystem, Use High Resolution and LiDAR Data. Journal of Environment and Earth Science, $7(10)$.

Ikhwan, M. (2013). Aplikasi Penginderaan Jauh untuk Mengidentifikasi Distribusi Suhu Pemukaan di Kota Pekanbaru. Universitas Riau.

Nofrizal, A. Y. (2017). Normallized Difference Builtup Index Sebagai Parameter Identifikasi Perkembangan Permukiman Kumuh Pada Kawasan Pesisir Di Kelurahan Kalang Kawal, Kecamatan Gunung Kijang, Kabupaten Bintan. Tunas 
Geografi, 6(2), 143-150.

Nofrizal, A. Y. (2018). Identifikasi Perubahan Penggunaan Lahan di Kota Solok, Sumatera Barat Berbasis Penginderaan Jauh dan SIG dengan menggunakan Object Base Image Analyst (OBIA). In GEOTIK (pp. 96104).

Tursilowati, L. (2002). UrbanHeat Island Dan Kontribusinya Pada Perubahan Iklim Dan Hubungannya dengan Perubahan Lahan. In Seminar Nasional Pemanasan Global dan Perubahan Global. Fakta. Mitigasi. Dan Adaptasi (pp. 89-96). Pusat
Pemanfaatan Sains Atmosfer dan Iklim, LAPAN.

Tursilowati, L. (2007). Use Of Remote Sensing And Gis To Compute Temperature Humidity Index As Human Comfort Indicator Relate With Land Use-Land Cover Change (LULC) In Surabaya. In The 73th International Symposium on Sustainable Humanosphere (pp. 160-166).

Wiweka. (2014). Pola Suhu Permukaan Dan Udara Menggunakan Citra Satelit Landsat Multitemporal. Ecolab, 8(1), 1-24. 